\title{
浄水污泥に含まれる有機物の分解と せん断特性の関係に関する基礎的研究
}

\author{
渡邊 保貴 1 - 小峯 秀雄 2 -村上 哲 3 - 安原 一哉 4 - 豊田 和弘 5 \\ 1正会員 一般財団法人電力中央研究所 地球工学研究所 バックエンド研究センター \\ （厂270-1194 千葉県我孫子市我孫子1646） \\ E-mail: yasutaka@criepi.denken.or.jp \\ 2 正会員 茨城大学教授 工学部都市システム工学科（テ316-8511 茨城県日立市中成沢町4-12-1） \\ E-mail: hkomine@mx.ibaraki.ac.jp \\ 3正会員 茨城大学准教授 工学部都市システム工学科（†316-8511 茨城県日立市中成沢町4-12-1） \\ E-mail: murakami@mx.ibaraki.ac.jp \\ 4 フェロー会員 茨城大学名誉教授 地球変動適応科学研究機関(ICAS) 産官学連携研究員 \\ （干310-8512 茨城県水戸市文京2-1-1） \\ E-mail: yasuhara@mx.ibaraki.ac.jp
}

5非会員＼cjkstart茨城県日立市企業局上下水道局（干316-0025 茨城県日立市森山町4-4-1）

\begin{abstract}
水道事業から排出される浄水污泥には多くの有機物が含まれている. 浄水污泥は一般的な土とは異なる 生成過程を経て排出されるため, 有機物の組成や分解特性に関して未知の部分が多く, 地盤材料として有 効利用する上で，工学的性質に及ぼす有機物の分解に関する経験的な解釈が通用するとは限らない。本研 究では，浄水污泥に含まれる有機物の組成および好気環境下における分解特性を明らかにすると共に，有 機物分解後の浄水污泥の三軸せん断特性を調査した。浄水污泥にはフミン酸が多く含まれており，フミン 酸の約 $44 \%$ は約 6 力月間で好気分解されることを明らかにした. また, 浄水污泥の有機物が約 $1.38 \%$ 分解さ れることにより, 内部摩擦角は $39.7^{\circ} \sim 40.4^{\circ}$ の範囲から $37.9^{\circ}$ 付近まで減少することを示した.
\end{abstract}

Key Words : waste, drinking water sludge, organic matter, humic acid, decomposition, shear strength

\section{1. 背景と目的}

水道事業の浄化処理過程では污泥(以後, 浄水污泥と 記述する)が排出される．写真-1に天日乾燥過程におけ る浄水污泥の外観を示寸．現在，浄水污泥は産業廃棄物 に分類されており，有効利用により最終処分量の削減に 努めることが肝要である. 我が国における浄水污泥の有 効利用率は増加傾向にあり, 平成20年度の実績は63\%で あった"1).我が国では，園芸用土やグラウンド用土とし て浄水污泥を利用することが多い2．建設資材としての 利用として, 道路の路床材料, 軽量盛土, 最終処分場の 即日覆土等の地盤材料としての利用に関寸る研究も進め られている4, 5) の. 以上の有効利用が普及寸ることに伴い, 浄水污泥を利用した後の視点, 具体的には, 材料の劣化 について明らかにすることが浄水污泥の安全かつ適正な 利用を推進する上では重要になると考えられる.

一般的に土は岩石の風化作用など非常に長い時間を経
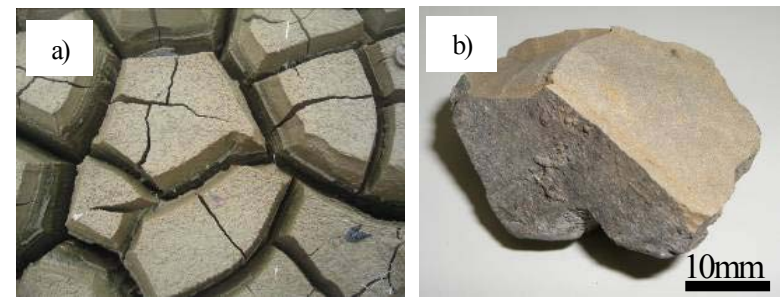

写真-1 天日乾燥過程における浄水污泥の外観 a) 含水比 $500 \sim 1500 \%$ b) 含水比約 $30 \%$

て生成されるものであり，土木事業の対象となる期間で は安定した物質であると考えられてきた，その一方で, 浄水污泥は河川や湖沼の水中に存在していた微粒子や有 機物を凝集剂を用いて凝集・沈殿させて生成させた物質 であり，一般的な土とは生成過程が著しく異なる，その ため, 浄水污泥の中・長期的な安定性を利用する前に確 認しておく必要性は高い。渡邊らわは, 凝集剤ポリ塩化 アルミニウムの架橋作用によりフロックあるいは団粒が 
形成されていることに着目し，浄水污泥に含まれる凝集 剤成分Alの溶出を促進させることにより化学的変質を模 擬し，化学的变質後の供試体を用いて定ひずみ速度載荷 による圧密試験を行った，その結果，A1溶出の圧縮性一 の影響はきわめて小さいが，透水性は低下寸ることを明 らかにしている。

浄水污泥の化学的な特徵として, 有機物を多く含む点 が挙げられる. 既往の研究5), 0, から, 浄水污泥の強熱減 量は茨城県日立市において 9.0 ～28.9\%の範囲で変動する ことが分かっている．全国的には，活性炭が含まれた浄 水污泥で強熱減量は $50.5 \%$ と非常に高い值になる ${ }^{8)}$. 浄水 污泥の有機物は，凝集・沈殿過程を経て粘土粒子と複合 的に集積していると考えられるため，一般的な土とは有 機物の組成や分解特性は異なるものと予想される.これ まで, 地盤工学の分野では, 有機物は土のコンシステン シ一，せん断，圧密特性等に影響を及ぼすと言われてき た"．その一方で，腐植物質を主とする有機物の分解に は非常に長い期間を要するため, 有機物の分解と工学的 性質の関係性を言及することの優先度は必ずしも高くは なかった. しかし, 前述した通り, 浄水污泥のような廃 棄物を地盤材料として利用寸る場合には，有機物の組成 や分解特性が未知であるため, 中・長期的な安全性を評 価する上でも，有機物の分解特性を明らかにすることは 重要である. そこで, 本研究では, 浄水污泥に含まれる 有機物の組成を調查すると共に，好気環境下における分 解特性を明らかにすることを目的と寸る. そして, 浄水 污泥のせん断特性に及ぼす有機物分解の影響を調査する ことにより, 浄水污泥の地盤工学的利用において有機物 分解を検討することの重要性について考察する.

\section{2. 浄水污泥に含まれる有機物}

本章では, 浄水污泥の基本的性質として物理的・化学 的性質, 鉱物組成, 化学組成について記述する. 浄水污 泥に含まれる有機物については, 強熱減量試験を行うと 共に, 酸・アルカリ抽出によりフミン酸, フルボ酸, ヒ ユーミンを含む土粒子の構成割合を明らかにした.

\section{（1）浄水污泥の基本的性質}

本研究において使用した試料は, 茨城県日立市森山浄 水場において採取した浄水污泥である. 原水は一級河川 久慈川から取水しており, 凝集剤にはポリ塩化アルミニ ウムが使用されている. 使用した浄水污泥に活性炭は含 まれていない.

浄水污泥の物理的・化学的性質を表-1に示寸. 浄水污 泥A， B, Eは天日乾燥, 浄水污泥 $\mathrm{C}, \mathrm{D}, \mathrm{F}, \mathrm{G}$ は加圧脱 水された試料である. 土粒子の密度と強熱減量はそれぞ れ日本工業規格JS A 1202: 1999, JS A 1226: 2000に準拠し
表-1 浄水污泥の物理的 - 化学的性質

\begin{tabular}{|c|c|c|c|c|}
\hline 試料名 & $\begin{array}{c}\text { 土粒子の密 } \\
\text { 度 }\left(\mathrm{g} / \mathrm{cm}^{3}\right)\end{array}$ & $\begin{array}{c}\text { 液性限 } \\
\text { 界(\%) }\end{array}$ & $\begin{array}{c}\text { 塑性限 } \\
\text { 界(\%) }\end{array}$ & $\begin{array}{c}\text { 強熱減 } \\
\text { 量 }(\%)\end{array}$ \\
\hline $\mathrm{A}$ & 2.58 & 224 & 145 & 17.6 \\
\hline $\mathrm{B}$ & 2.61 & 178 & 104 & 18.8 \\
\hline $\mathrm{C}$ & 2.52 & 269 & 151 & 26.6 \\
\hline $\mathrm{D}$ & 2.45 & 113 & 91 & 27.3 \\
\hline $\mathrm{E}$ & 2.54 & & & 17.1 \\
\hline $\mathrm{F}$ & 2.65 & & & 22.1 \\
\hline $\mathrm{G}$ & 2.45 & & & 19.1 \\
\hline
\end{tabular}

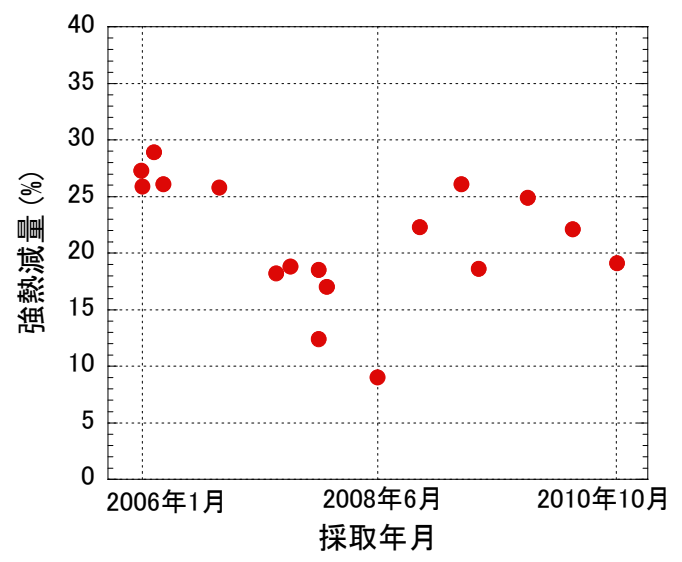

図-1 茨城県日立市における浄水污泥の強熱減量

表-2 浄水污泥の化学組成

\begin{tabular}{|l|c|c|c|c|}
\hline \multirow{2}{*}{ 試料名 } & \multicolumn{3}{|c|}{ 浄水污泥 } & 発生土 \\
\cline { 2 - 4 } & $\mathrm{C}$ & $\mathrm{E}$ & $\mathrm{F}$ & N.S* \\
\hline $\mathrm{SiO}_{2}(\%)$ & 46 & 44 & 46 & 61 \\
\hline $\mathrm{Al}_{2} \mathrm{O}_{3}(\%)$ & 24 & 24 & 24 & 16 \\
\hline $\mathrm{Fe}_{2} \mathrm{O}_{3}(\%)$ & 5.8 & 4.9 & 5.8 & 8.2 \\
\hline $\mathrm{CaO}(\%)$ & 1.9 & 1.2 & 1.9 & 0.6 \\
\hline $\mathrm{MgO}(\%)$ & 1.0 & 1.1 & 1.0 & 0.8 \\
\hline $\mathrm{Na}_{2} \mathrm{O}(\%)$ & 1.0 & 1.3 & 1.0 & 0.9 \\
\hline $\mathrm{K}_{2} \mathrm{O}(\%)$ & 1.3 & 1.6 & 1.3 & 1.1 \\
\hline $\mathrm{P}_{2} \mathrm{O}_{5}(\%)$ & 0.59 & 0.44 & 0.59 & 0.04 \\
\hline
\end{tabular}

*N.S は茨城県日立市内の埋設管工事の発生土である.

て測定した。液性限界・塑性限界試験は, JIS A 1205: 2009に準拠して実施した. 寸なわち, 室温 $20^{\circ} \mathrm{C} て ゙$ 水分を 蒸発させながら含水比を低下させる過程で液性限界と塑 性限界を測定した。浄水污泥の強熱減量は, 図-1に示す ように排出される時期により 9.0 28.9\%の範囲で変動す ることが分かっており, 表-1に示寸強熱減量はその範囲 内である. 浄水污泥の強熱減量が高い理由は, 主に取水 (河川水)に含まれていた有機物が凝集されたためと推察 される.

浄水污泥の化学組成を表-2に示寸. 分析には蛍光X線 分析装置(3270E/理学電機)を用いた。強熱減量の割合を 全体から差し引き, 酸化物形態に換算した乾燥質量の百 
分率で結果を表示した. また, 浄水污泥の比較対象とし て茨城県日立市森山浄水場内の埋設管工事にて排出され た発生土N.S $\left(L_{i}=7.5 \%\right)$ の化学組成を併記した. 割合浄水 污泥は発生土N.S と比べると, $\mathrm{SiO}_{2}$ の割合が小さく,

$\mathrm{Al}_{2} \mathrm{O}_{3}$ の割合が大きい. 一般的な土と比べて浄水污泥に は有機物が多く含まれるために石英等の鉱物の割合が相 対的に減少し，また，凝集剂ポリ塩化アルミニウムの成 分が残留していることが推察される.

\section{（2）有機物の組成}

一般的に土壌中の有機物は，酸とアルカリに対する溶 解性の違いからフルボ酸(fulvic acid)，フミン酸(humic acid), ヒューミン(humin)に分類される. 図-2に示すように，フ ルボ酸は酸とアルカリの両方に溶解し，フミン酸はアル カリにのみ溶解する. 浄水污泥に含まれる有機物の組成 を明らかにするため, 酸・アルカリ抽出を行った.

酸・アルカリ抽出の手順は以下の通りである ${ }^{10,111,12) .}$

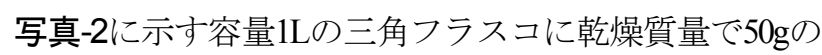
試料を投入し，液固比 $10 \mathrm{Lkg}$ になるように $0.5 \mathrm{~mol} / \mathrm{L} の$ NaOHを500g添加した，混合溶液は，試料全体が流動す るように24時間スターラー擋拌した。擋找中は試料の流 出を防ぐため, ラップ，輪ゴム，ビニルテープで三角フ ラスコ上部を塞いだ。浄水污泥は擋拌スターラー擋拌後, 混合溶液を $3000 \mathrm{rpm}$ で30分間遠心分離し，沈殿物と上澄 み液を得た. 遠心分離により沈殿した物質はヒューミン を含む土粒子である. 上澄夕液は $6 \mathrm{~mol} / \mathrm{L} の \mathrm{HCl}$ で $\mathrm{pH} 2.0$ ま で調整した. $\mathrm{pH}$ 調整後の液体を再び遠心分離し，この とき，アルカリに可溶かつ酸に不溶のフミン酸が沈殿物 として分離される．上澄み液には酸にも可溶なフルボ酸 が含まれている，上澄み液のフルボ酸の濃度を調べるた

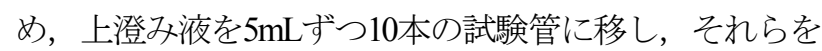
$110^{\circ} \mathrm{C}$ で質量一定になるまで炉乾燥した後の乾燥質量を 計測した。上澄み液の量とフルボ酸の濃度からフルボ酸 の質量を算出した．塩の除去は行っていないため, ここ で算出されるフルボ酸には塩の質量も含まれている。な お，後述する試験結果より，フルボ酸の割合はフミン酸

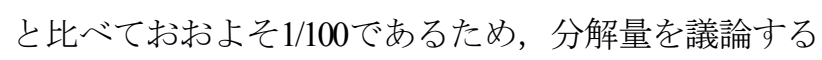
上でフルボ酸が塩等の溶解物質を含んだ質量で表わされ ていても論旨には影響しない.

酸・アルカリへの可溶性に基づいた浄水污泥に含まれ る有機物の割合を表-3に示寸. 浄水污泥に最も多く含ま れていたのはヒューミンを含む土粒子であり，その割合 は90.70 98.78\%であった. 一方, 発生土N.Sのヒューミ ンを含む土粒子の割合は $99.72 \%$ あ゙あた．次に割合が多 かったのはフミン酸であり, 浄水污泥には1.20 9.27\%の 範囲で含まれていた，その值は発生土N.Sと比べると約5 〜37倍にあたり，フミン酸が多く含まれていることが浄 水污泥の特徵であると言える. これは, 浄化処理過程に

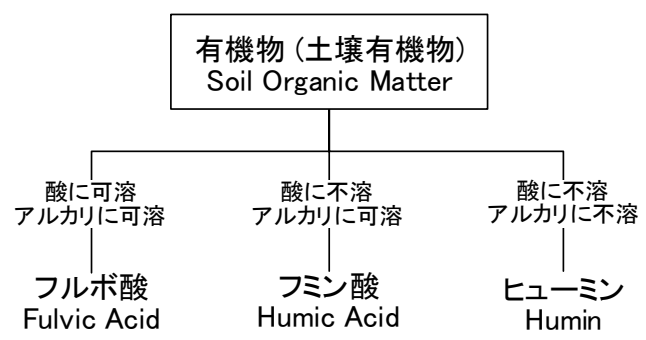

図-2 酸・アルカリへの可溶性に基づいた有機物の分類

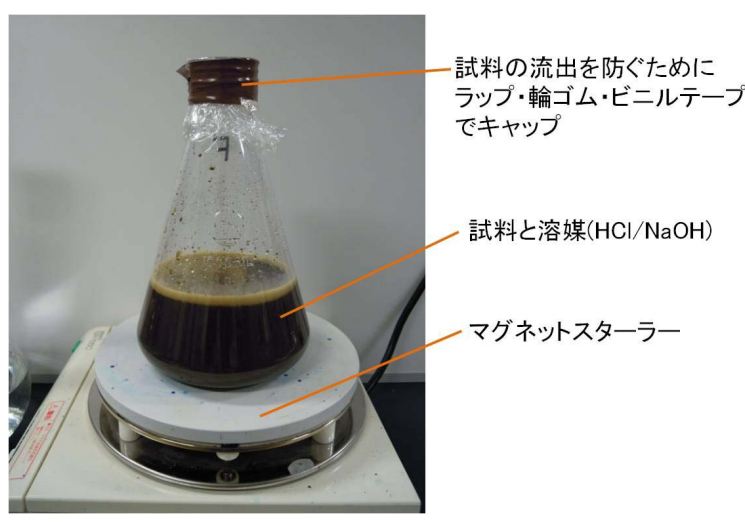

写真-2 酸・アルカリ抽出に用いた試験装置

表-3 酸・アルカリへの可溶性に基づいた浄水污泥に含ま れる有機物の割合

\begin{tabular}{|c|c|c|c|}
\hline 試料名 & $\begin{array}{c}\text { フルボ酸 } \\
(\%)\end{array}$ & $\begin{array}{c}\text { フミン酸 } \\
(\%)\end{array}$ & $\begin{array}{c}\text { ヒューミンを含 } \\
\text { む土粒子(\%) }\end{array}$ \\
\hline $\mathrm{A}$ & 0.039 & 3.14 & 96.82 \\
\hline $\mathrm{B}$ & 0.032 & 2.39 & 97.58 \\
\hline $\mathrm{C}$ & 0.034 & 9.27 & 90.70 \\
\hline $\mathrm{D}$ & 0.040 & 4.31 & 95.65 \\
\hline $\mathrm{E}$ & 0.016 & 1.20 & 98.78 \\
\hline $\mathrm{F}$ & 0.049 & 3.90 & 96.05 \\
\hline $\mathrm{G}$ & 0.036 & 5.14 & 94.82 \\
\hline $\mathrm{N} . \mathrm{S}$ & 0.028 & 0.25 & 99.72 \\
\hline
\end{tabular}

おいて比較的分子量の大きい $(1000 \sim 1500$ 以上 $)$ フミン酸 類に対して，凝集効果が高いことに由来すると考えられ $3^{13)}$. 浄水污泥に含まれるフルボ酸の割合は $0.016 〜$ $0.040 \%$ であり，フミン酸と比べると含有量は非常に少な い. また，浄水污泥に含まれるフルボ酸の割合は発生土 N.Sとほとんど同じであったことから, 浄水污泥のフル ボ酸含有量は，一般的な土と同程度であると考えられる。

\section{3. 好気環境下における有機物の分解特性}

2章では，浄水污泥に含まれる有機物の組成は一般的 な土とは異なることを明らかにした. そのため, 浄水污 泥に含まれる有機物に関して, 分解特性を把握しておく ことが浄水污泥の安全な利用に結びつくと考えられる. 本章では, 浄水污泥に含まれる有機物の好気環境下にお 
ける分解特性を明らかにする.

\section{（1）試料の養生と土壤呼吸速度の測定方法}

本研究では，好気環境下における有機物の分解特性を 把握するため, 浄水污泥を含水比一定のもとに養生し, 定期的に土壊呼吸速度と強熱減量を測定した。土中では, 植物根の呼吸や微生物による有機物の分解により $\mathrm{CO}_{2}$ が 排出され，土中の $\mathrm{CO}_{2}$ 濃度は大気中より高くなる. しか しながら，土中の $\mathrm{CO}_{2}$ 濃度は土の排気性や排水性，ある いは深さによって大きく異なり ${ }^{14)}$ ，微生物の活動圏とな る微小な間隙における $\mathrm{CO}_{2}$ 濃度を把握することは困難で ある. 以上の理由より，本研究では基礎的検討として， 好気環境下における有機物の分解特性を調査した.

使用した試料は表-3に試料名 $\mathrm{F}$ と $\mathrm{G}$ で示される浄水污 泥である.また，河川流域が異なる場合に有機物の分解 特性が変化することを想定し，千葉県佐倉市の佐倉浄水 場において採取した浄水污泥(以後，浄水污泥Sと記述す る)も用いた。佐倉浄水場では，原水を鹿島川と印旛沼 から取水し，工業用水を供給している。凝集剤として塩 化アルミニウムが使用されている. 試料 $\mathrm{S} の$ 強熱減量は 25.4\%であった. 試料の団粒寸法は，2mm以下にほぐし たものと 2 19mmに分級したものの二種類を用いた。 た だし，試料Gに関しては，2mm以下の試料の量を十分に 確保できなかったため，2～19mmに分級した試料のみを 使用した. 各試料は加圧脱水された直後のものを採取し, 同一条件で養生した。

養生期間内に各試料の含水比が変化し, 微生物の活性 が変化すること ${ }^{15)}$ を最小限に抑えるため，ステンレス製 の容器に入れた後, 空気を極力抜いた状態でラップをし

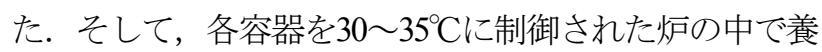

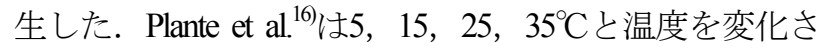
せた場合， $35^{\circ} \mathrm{C}$ ケースで最も二酸化炭素の排出量が多 いことを示しており，本研究では微生物による有機物の 分解がより顕著となる条件を選定したと言える. 試料F, G，Sについて含水比の変動幅はそれぞれ $150 １ 66 \%$, 108〜123\%，132〜158\%であった．養生している間，含 水比の変化を小さくすることを優先していたため, 容器 内の空気量は少なかったが，およそ月一度の間隔で空気 の入れ替えを行い，養生中も微生物による有機物の分解 は進行していたと考えられる。

恒温状態で養生した試料の一部を定期的に取り出し, 土畩呼吸速度と強熱減量を測定した。土壌呼吸速度とは, 単位質量, 単位時間あたりの $\mathrm{CO}_{2}$ 発生量 $[\mathrm{mg} / \mathrm{kg} / \mathrm{d}]$ として 定義され，一般的には土壌の肥沃性に関わる土壌バイオ マスの測定に活用されており ${ }^{17)}$ ，葉の暗呼吸や根の活性 を把握するための指標としても類似した測定が実践され ている ${ }^{18), 19)}$ 。本研究では，微生物の活性を間接的に調査 することを目的に土壌呼吸速度を測定した。本研究で用

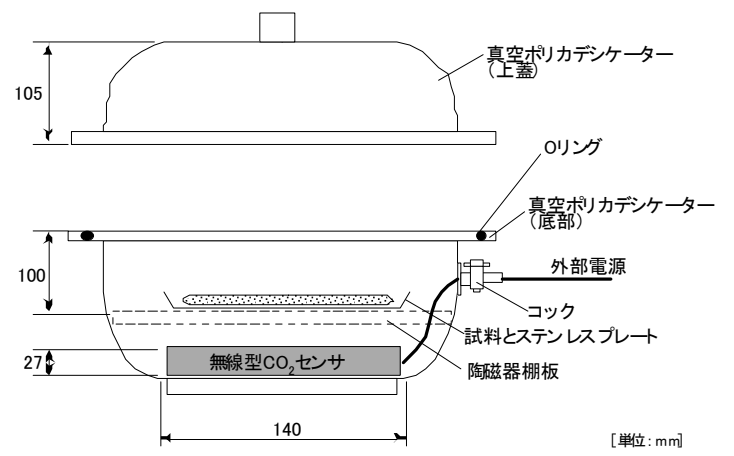

図-3 土壤呼吸速度測定装置

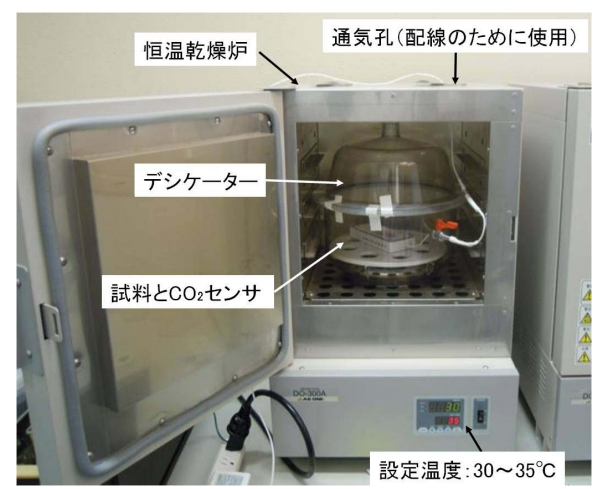

写真-3 土壌呼吸速度測定装置の設置状況

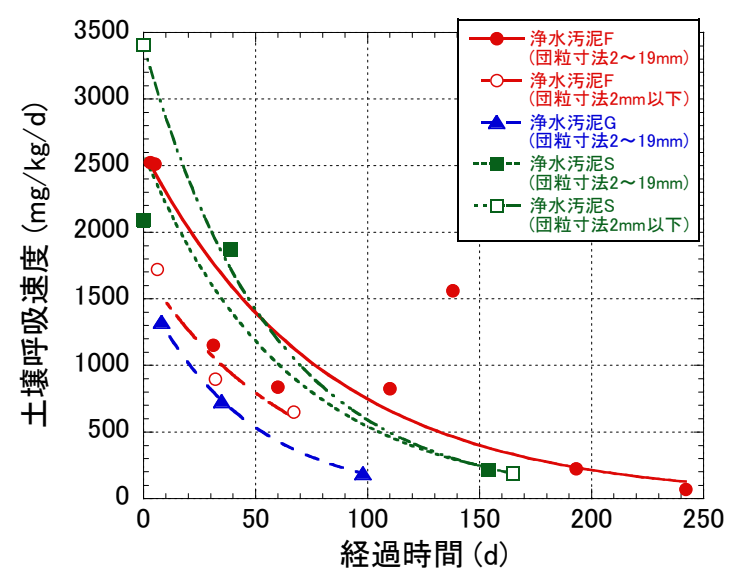

図-4 二酸化炭素排出量と経過時間の関係 $\left(30 \sim 35^{\circ} \mathrm{C}\right)$

いた土壌呼吸速度測定装置を図-3と写真-3に示す。デシ ケーターの底部に $\mathrm{CO}_{2}$ センサ $(\mathrm{C} 2 \mathrm{D}-\mathrm{W} 02 \mathrm{TR} /$ 株式会社ユ 一・ドム)を, 陶磁器棚板の上に試料を設置した. $\mathrm{CO}_{2}$ セ ンサの測定範囲は $\mathrm{CO}_{2}$ 濃度で $0 \sim 5000 \mu \mathrm{L} / \mathrm{L}$ (分解能 $1 \mu \mathrm{L} / \mathrm{L}$ ), 温度で $-20 \sim 80{ }^{\circ} \mathrm{C}$ (分解能 $0.1{ }^{\circ} \mathrm{C}$ ), 相対湿度で 0 $100 \% \mathrm{RH}($ 分解能 $0.1 \%$ )である. 測定間隔は60秒/回とした. $\mathrm{CO}_{2}$ 発生量の測定は養生時と同じ密閉容器, 同じ温度下 で実施した。すなわち，乾燥質量で20～30gの試料をデ シケーター内に静置した後, デシケーターの上蓋と底部 をOリングと高真空シール用オイルコンパウンド (HIVAC-G)で密着させ，さらにパラフィルムとビニルテ 
ープで外側からもシールし，密閉性を高めた。 なお，試 料を設置しない状態でデシケーター内部の $\mathrm{CO}_{2}$ 濃度が一 定值で推移すること，温度と湿度の影響を受けないこと を事前に確認している． $\mathrm{CO}_{2}$ 濃度の測定時間は24時間と した．なお，試料採取から2日以内に一度目の測定を実 施ている.

$\mathrm{CO}_{2}$ 排出量 $M_{\mathrm{CO} 2}(\mathrm{~g})$ の計算は以下の通りである. 24時間 で測定されたデシケーター内の $\mathrm{CO}_{2}$ 濃度増加分 $C(\mu \mathrm{L} \mathrm{L})$, デシケーターの容積 $V(\mathrm{~L})$, 温度 $T\left({ }^{\circ} \mathrm{C}\right)$ と気圧 $P(\mathrm{~Pa})$ は一定 の条件の下, 式(1)でボイル・シャルルの法則よりデシ ケーター内の $\mathrm{CO}_{2}$ の体積を標準状態 $\left(0^{\circ} \mathrm{C} ， 101325 \mathrm{~Pa}\right)$ にお ける体積 $V_{\mathrm{CO} 2}$ に換算し，式(2)により24時間でデシケータ 一内において増加した $\mathrm{CO}_{2}$ の質量 $M_{\mathrm{CO} 2}$ を求めた。

$$
\begin{gathered}
V_{\mathrm{CO} 2}=\frac{V \times C \times 10^{-6} \times 273}{T+273} \\
M_{\mathrm{CO} 2}=\frac{V_{\mathrm{CO} 2}}{22.4} \times 44
\end{gathered}
$$

ここに，既知の実験条件として，Vは 9.41L， $T$ は $20^{\circ} \mathrm{C,}$ $\mathrm{CO}_{2}$ の分子量は 44, 理想気体 $1 \mathrm{~mol}$ の体積は $22.4 \mathrm{~L}$ とた.

浄水污泥からの $\mathrm{CO}_{2}$ 排出量を 24 時間測定した後, JIS A 1226:2000 に準拠して試料の強熱減量を測定した. $\mathrm{CO}_{2}$ 排出量の測定に用いた試料の残りは，他の $\mathrm{CO}_{2}$ 測定て使 い回さずに処分した.

\section{（2）浄水污泥の土壌呼吸速度および強熱減量の推移}

浄水污泥の土壤呼吸速度と経過時間の関係を図-4に示 す. 図中の曲線は，試験結果を指数関数で近似した曲線 であり，指数関数を選択した理論的根拠は次節に後述す る. 土壤呼吸速度は初期に最も高く, 時間の経過と共に 減少する傾向が認められた．浄水污泥Fに関しては，団 粒寸法2 $19 \mathrm{~mm}$ の方が土壤呼吸速度は大きかった。 その 一つの要因としては，24時間の測定の間に，団粒寸法2 〜 $19 \mathrm{~mm}$ と $2 \mathrm{~mm}$ 以下の試料の含水比が166\%からそれぞれ 139\%と132\%まで低下しており，団粒寸法が小さいほど 比表面積も大きいため乾燥が著しかったことから，より 乾燥した団粒寸法 $2 \mathrm{~mm}$ 以下の環境では微生物の活性は低 下していたことが考えられる. 団粒寸法2１9mmに限る と土壤呼吸速度の值は浄水污泥Fおよびが $\mathrm{G}$ と比べて比 較的大きかった。こうした結果には含水比だけでなく強 熱減量等の大小も影響しており, 強熱減量は易分解性の 有機物量と関係性があると予想されるが，明確な理由は 現時点で不明である. 図-5に強熱減量と経過時間の関係 を示す．時間の経過と共に強熱減量は減少する傾向が認 められた. 浄水污泥 $S$ の団粒寸法 $2 \sim 19 \mathrm{~mm}$ のケースを除 いて強熱減量の減少率は1３\%であった．浄水污泥Fに 関して約6カ月が経過した時点でフルボ酸とフミン酸の 割合を調べたところ，図-6に示すようにフミン酸は約 44\%減少し，フルボ酸は約 $51 \%$ 増加していた。 フミン酸

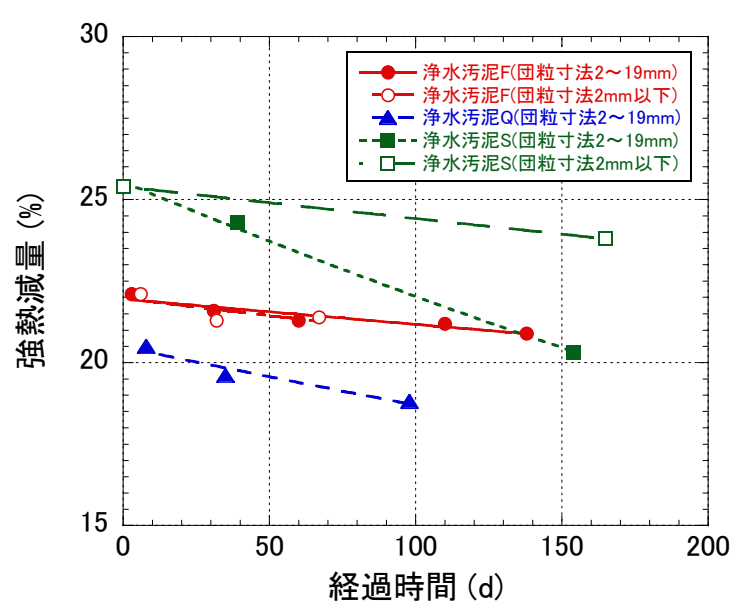

図-5 強熱減量と経過時間の関係 $\left(30 \sim 35^{\circ} \mathrm{C}\right)$

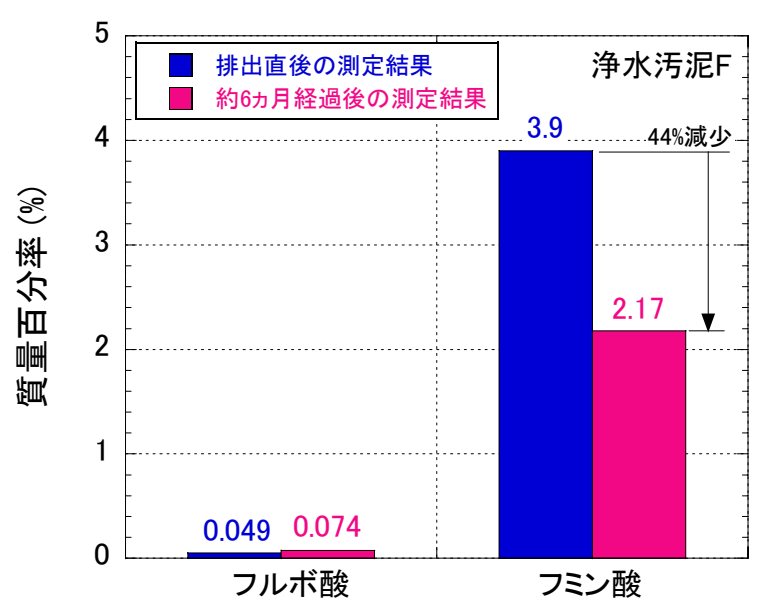

図-6 約 6 力月経過時点における有機物の組成

表-4＼cjkstart試験結果のフィッティングパラメーター

\begin{tabular}{|c|c|c|c|}
\hline & 試料 & $\alpha$ & $\beta$ \\
\hline CASE1 & $\begin{array}{c}\text { 浄水污泥 F } \\
\text { (団粒寸法 2 } 19 \mathrm{~mm} \text { ) }\end{array}$ & 2607.1 & $1.25 \times 10^{-2}$ \\
\hline CASE2 & $\begin{array}{c}\text { 浄水污泥 F } \\
\text { (団粒寸法 } 2 \mathrm{~mm} \text { 以下) }\end{array}$ & 1725.1 & $1.55 \times 10^{-2}$ \\
\hline CASE3 & $\begin{array}{c}\text { 浄水污泥 G } \\
\text { (団粒寸法 2 } 19 \mathrm{~mm} \text { ) }\end{array}$ & 1563.9 & $2.15 \times 10^{-2}$ \\
\hline CASE4 & $\begin{array}{c}\text { 浄水污泥 S } \\
\text { (団粒寸法 2 } ~ 19 \mathrm{~mm} \text { ) }\end{array}$ & 2589.8 & $1.57 \times 10^{-2}$ \\
\hline CASE5 & $\begin{array}{c}\text { 浄水污泥 S } \\
\text { (団粒寸法 } 2 \mathrm{~mm} \text { 以下) }\end{array}$ & 3408.0 & $1.75 \times 10^{-2}$ \\
\hline
\end{tabular}

の減少は，微生物による有機物分解により有機物が消失 したことを示していると考えられる.フルボ酸の増加に ついては, フルボ酸の割合は小さいため測定精度上の問 題もあるが，一部のフミン酸を構成する分子が低分子化 し，より分子量の小さいフルボ酸として質量増分に現れ た可能性が考えられる．なお，土粒子との区別が難しい ためヒューミンの定量は行っていない. 


\section{（3）炭素収支の観点における好気性分解の判定}

本研究では, 土壌呼吸速度の測定時や試料の養生期間 中にO 濃度を管理していないため，有機物の分解が好気 環境のもとに行われていたことを確認する必要がある. 好気環境下における有機物の分解では, $\mathrm{CO}_{2}$ 濃度の増加 と $\mathrm{O}_{2}$ 濃度の減少が釣り合い，嫌気環境下においては $\mathrm{CO}_{2}$ と $\mathrm{CH}_{4}$ が同時に生成される ${ }^{200}$. そのため, 好気環境であ れば発生した $\mathrm{CO}_{2}$ の炭素はほぼすべて有機物由来であり， 土壤呼吸速度と強熱減量の炭素収支を通して好気性分解 の判定が可能であると考えられる，一方，嫌気環境下で は, $\mathrm{CH}_{4}$ の生成にも有機物由来の炭素が消費されるため, 土壤呼吸速度から計算される炭素量は強熱減量から計算 される炭素量とは釣り合わない.

Jenny ${ }^{21,22)}$ は一つの土壤系の中で有機物の添加と分解が 同時に起こる時, 土壌有機物の変化量 $d X / d t$ は新たな有 機物の添加量 $A$ から土壤有機物の分解量 $r X$ を差し引い たものであるとし，次のように表した.

$$
\frac{d X}{d t}=A-r X
$$

ここに，r はある一定期間の分解率(一定值)である. 式 (3)を積分すると, 有機物の分解量は式(4)として与えら れる.

$$
r X=A-\left(A-r X_{0}\right) e^{-r t}
$$

$X_{0}$ は試験開始時における土壤有機物量である.ここで, 浄水污泥に含まれる有機物の分解を考える場合は， $X_{0}$ は 浄水污泥に含まれる初期の有機物量である. 浄水污泥の 利用期間中に新たな有機物の添加はないと考えて $A$ を 無視すると, 浄水污泥に含まれる有機物の分解量は式 (5)のように表わされる.

$$
r X=r X_{0} e^{-r t}
$$

分解率 $r$ は定数であるため, 式(5)の両辺から $r$ を消去す ると式(6)のようになり, 有機物量 $X$ は時間 $t$ の指数関数 で表わされる。

$$
X=X_{0} e^{-r t}
$$

以上より，図-4に示した土袞呼吸速度と経過時間の 関係に対して，好気性分解の場合は $\mathrm{CO}_{2}$ 排出量と有機物 分解量に相関があることと，ある時期の有機物量は一定 の分解率の時間の関数で与えられることを仮定し，式 (6) と同様の指数関数で近似した. 寸なわち，近似曲線 の形を式(7)で与える.

$$
q_{\mathrm{CO} 2}=\alpha e^{-\beta t}
$$

ここに， $q_{\mathrm{CO} 2}$ は土袞呼吸速度 $[\mathrm{mg} / \mathrm{kg} / \mathrm{d}]$ である.フィッテ イングパラメーターの $\alpha$ は排出直後の浄水污泥から生じ る $\mathrm{CO}_{2}$ 排出量, $\beta$ は $\mathrm{CO}_{2}$ 排出量の減少率に相当寸る. 各係

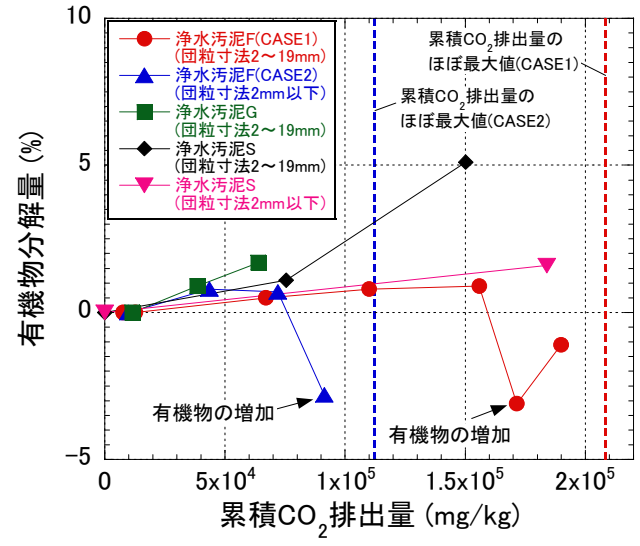

図-7 有機物分解量と累積 $\mathrm{CO}_{2}$ 排出量

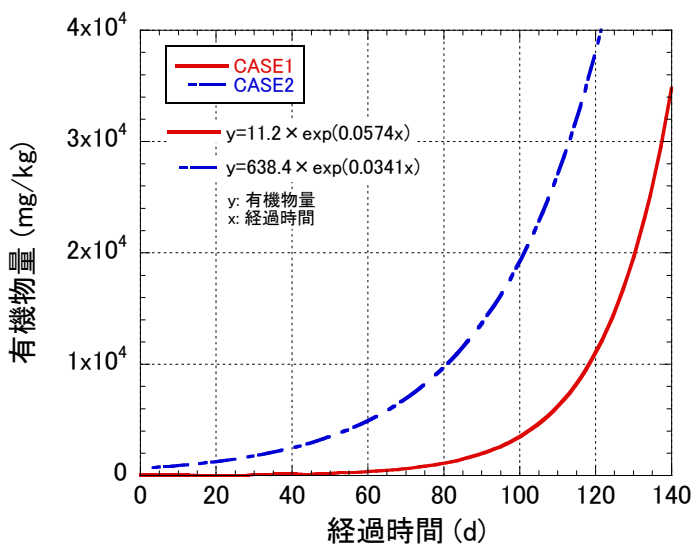

図-8 浄水污泥 Fに関して強熱減量の増分から得られた有機 の生成量を推計するフィッティングカーブ

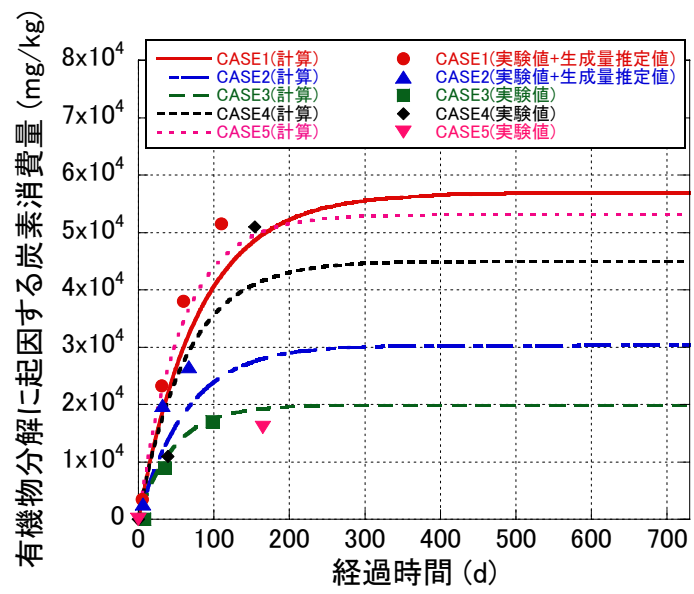

図-9 有機物分解に起因寸る炭素消費量と経過時間の関係 ※試験番号 CASE1～5 は表-4 と一致している. 式 (7)より求めた結果を「計算」，強熱減量の差分か ら求めた結果を「実験值」と表記している.

数の值を表-4にまとめた． $\alpha$ は団粒寸法の差異に起因す る含水比の分布により值が変動すると考えられる． $1.25 \times 10^{-2} \sim 2.15 \times 10^{-2}$ の範囲であった。 $\beta$ の物理的意味は有 機物の分解率である.ただし， $に$ には有機物の分解に関 わる複数の要因が丸め込まれており, 例えば微生物の種 類や数, 易生物分解性有機物の種類や量などが考えられ 
る. 本試験の測定系統においては，有機物分解特性に及 ぼす上記した項目の影響は互いに打ち消し合っていたた め, $\beta$ は限られた範囲内で得られたと考えられる. 本研 究では一つの試料に対する分解率を一定值とみなすが, 分解率の時間的な変化やそれと関係性のある要因につい ては今後の課題とする.

式(7)より，一日あたりの $\mathrm{CO}_{2}$ 排出量を求めることが できるので， $\beta$ が時間の経過に対して一定であるとの仮 定の下，式(7)を時間範囲 $t_{1}<t<t_{2}$ で積分すると累積 $\mathrm{CO}_{2}$ 排 出量 $Q_{\mathrm{CO} 2}[\mathrm{mg} / \mathrm{kg}]$ を求める式(8)が得られる. そして, $\mathrm{CO}_{2}$ から炭素 C の分子量に換算することにより, 式(9)から 有機物分解に起因する炭素消費量 $Q_{C}[\mathrm{mg} / \mathrm{kg}]$ が求まる.

$$
\begin{gathered}
Q_{\mathrm{CO}_{2}}=\int_{t_{1}}^{t_{2}} q_{\mathrm{CO} 2} d t=\frac{\alpha}{\beta}\left(e^{-\beta t_{1}}-e^{-\beta t_{2}}\right) \\
Q_{C}=\frac{\alpha}{\beta}\left(e^{-\beta t_{1}}-e^{-\beta t_{2}}\right) \times \frac{12}{44}
\end{gathered}
$$

有機物分解量すなわち有機物分解における炭素消費量 を算出するため, 強熱減量の差分を試料質量に乗じるこ とにより求めた. 強熱減量試験では, 炭酸塩類が $\mathrm{CO}_{2}$ と なり揮酸することにより無機物を含めた有機物含有量が 算出される問題もあるが，浄水污泥を養生する期間内に 炭酸塩類の生成や消失は有機物の増减に対してきわめて 微小であると考え，強熱減量の差分を用いることにより， 有機物分解で消費された炭素量を計算した．しかし，浄 水污泥の養生中には植物根の生育等により, 有機物が新 たに生成された可能性もある. 実際, 図-7に示すように 式(8)から計算される累積 $\mathrm{CO}_{2}$ 量がほぼ最大值に至る手前 で, 浄水污泥Fに関しては, 有機物分解量が減少し, 有 機物が増加していることがわかる。これは，土袞呼吸速 度が低下し，有機物の分解が概水完了した段階で有機物 の生成が支配的になったことを意味していると考えられ る. なお，浄水污泥Gに関しては測定期間が短いため有 機物の増加は確認されなかった。浄水污泥Sに関しては, 排出源が他の試料と異なるため理由は不明だが，測定期 間内に有機物が増加することはなかった，有機物が増加 した場合には，有機物増分を除外した実質の有機物分解 量を推計するため, 有機物の増加に対して式(10)を仮定 してあてはめ，図-8に示すように有機物生成量を求めた. 式(10)の適用範囲は試験期間内とする．また，ここでは 有機物の生成は分解と同時に起こる現象と考え, 式(6) に倣って式(10)を仮定したが，植物細胞の増殖に関する 記述がLockhartの一階の偏微分方程式を基礎に検討され ていることから ${ }^{23)}$ ，単純ではあるが妥当な仮定であると 考えられる.

$$
X^{\prime}=X_{0} e^{s t}
$$

ここに，X'は有機物の生成量， $X_{0}$ は試験開始時における

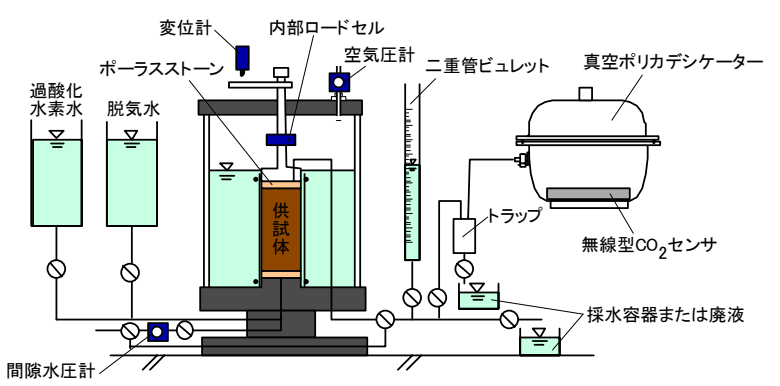

図-10 三軸圧縮試験装置の概略図

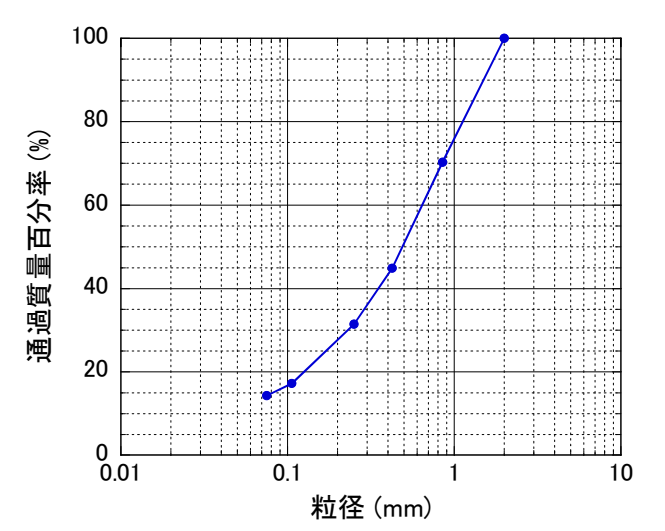

図-11 三軸圧縮試験で用いた浄水污泥 Aの粒径加積曲線

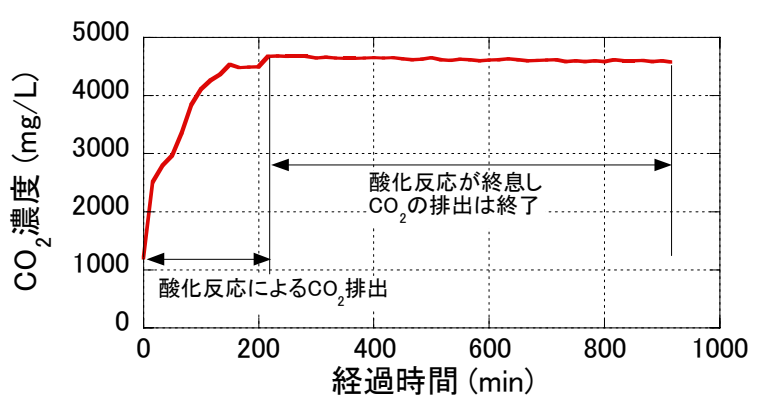

図-12 供試体の有機物分解過程における $\mathrm{CO}_{2}$ 濃度の推移

土壤有機物量，sは有機物の生成率である．式(10)につい てもある期間内の有機物生成量を求め, 強熱減量から正 味の有機物分解量を算出した. この補正は浄水污泥Fに ついてのみ行い, その他の試料に関しては有機物増加の 実験事実が得られなかったことから補正は行っていない. 有機物分解に起因寸る炭素消費量と経過時間の関係を 図-9に示寸. 浄水污泥 $\mathrm{S}$ (団粒寸法 $2 \mathrm{~mm}$ 以下)を除いて計算 結果と有機物分解に起因寸る炭素消費量 $Q_{C}$ の時間変化 が定性的に一致しており，ほぼ炭素収支がとれているこ とがわかる. これより, 浄水污泥 $\mathrm{S}$ (団粒寸法 $2 \mathrm{~mm}$ 以下) を除いて好気性分解が進行していたと判定される. 計算 值の方が炭素消費量は若干小さい傾向にあるが，実験式 (7)のフィッティングの段階で誤差が含まれていること， 好気性分解から嫌気性分解に推移寸ることにより $\mathrm{CO}_{2}$ 排 出量は減少したことが推察されること等が原因として考 
えられる. 浄水污泥 $\mathrm{S}$ (団粒寸法 $2 \mathrm{~mm}$ 以下)の結果に関し ては， $\mathrm{CO}_{2}$ 排出量は大きく強熱減量の低下は小さいこと から，その試料条件では有機物生成が顕著であった可能 性が考えられるが，式(10)を適用する上での根拠が不足 しているため, 有機物生成量の補正による検討は行わな いこととした．有機物の分解と生成を区別するための実 測值を入手寸ることが今後の課題である.

\section{4. せん断特性に及ぼす有機物分解の影響}

3章では，好気環境下において浄水污泥に含まれる有 機物は分解されることを確認した. 本章では, 浄水污泥 のせん断特性に及ぼす有機物分解の影響を三軸圧縮試験 により調査した結果を記述する．有機物分解の促進には 過酸化水素水を使用した.

\section{（1）三軸圧縮試験における供試体の作製方法および試 験方法}

浄水污泥のせん断特性に及ぼす有機物分解の影響を明 らかにするため，過酸化水素水を用いて有機物の分解を 促進した供試体に対して，圧密排水三軸圧縮試験を実施 した．本研究で使用した三軸圧縮試験装置を図-10に示 す. 供試体の寸法は高さ $100 \mathrm{~mm}$, 直径 $50 \mathrm{~mm}$ の円柱形で ある. 表-1に示した最適含水比に調整した浄水污泥Aを 粒径 $2 \mathrm{~mm}$ 以下に調整し, 動的締固めにより供試体を作製 した.ここで示寸粒径とは，2mmふるいを通過した浄水 污泥の団粒の直径である. 浄水污泥は不定形で排出され るため, 粒径は試料の保管方法や分級操作などに応じて 変化する. 本研究では, 試料の破砕方法と分級操作を可 能な限り統一寸るため, 突固めによる土の締固め試験方 法(JS A 1210: 2009)のE法に準拠して作製した供試体を手 でほぐし，2mmふるい通過分を用いて三軸圧縮試験用の 供試体を作製した．試料の粒径加積曲線を図-11に示寸， 動的締固めでは，三軸圧縮試験機のペデスタル上にモー ルドを設置し，ゴムスリーブを負圧で張った後，試料を 20層に分けて投入し，重量 $339.25 \mathrm{~g}$, 直径 $25.0 \mathrm{~mm}$ の突き棒 を各層30回, 高さ30mmから落下させた，目標の乾燥密 度は $0.82 \mathrm{~g} / \mathrm{cm}^{3}$, 締固め度は $75 \%$ である. 一般的に参考に される締固め規定である締固め度 $90 \%{ }^{24}$ は下回っている が，文献㫄において報告されている試験施工時の現場密 度試験の結果とほぼ同程度の值であり, 道路の路床材料 としては十分な要求性能が期待される状態である.

供試体作製後, $\mathrm{CO}_{2}$ を供試体下部から約30分間通気し, 間隙を $\mathrm{CO}_{2}$ に置き換えてから，6\%，9\%，15\%濃度の過酸 化水素水を通水した. 有機物の分解量を変化させるため, 各濃度の過酸化水素水を適宜組夕合わせて通水した. 過 酸化水素水を通水すると酸化反応により $\mathrm{CO}_{2}$ が生じ, 透 水性は低下寸るため, 動水勾配を約 5.0 として通水を行

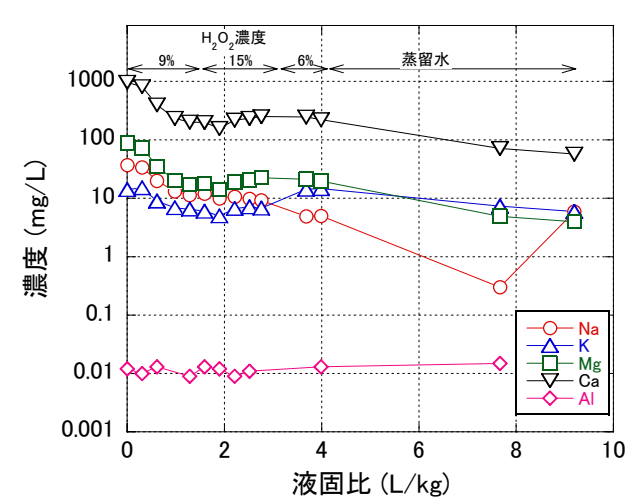

（a）過酸化水素水と蒸留水を通水した場合

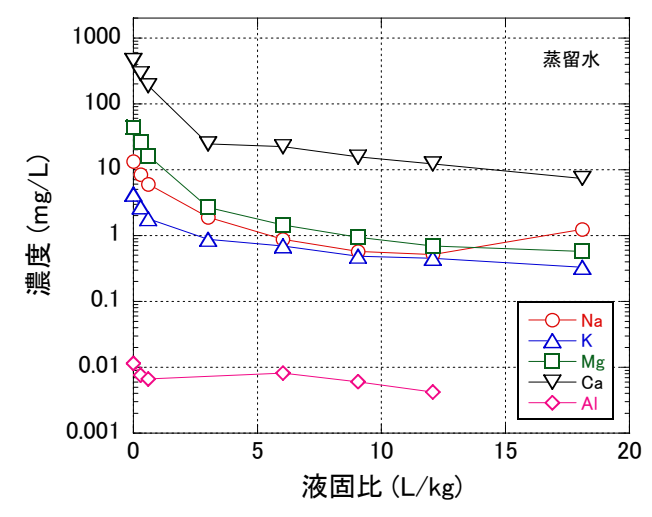

(b) 蒸留水を通水した場合

図-13 有機物分解過程における陽イオン溶出濃度

った. $\mathrm{CO}_{2}$ は水と共に供試体上部から排出され，トラッ プを介してデシケーターまで導いた. デシケーター内の $\mathrm{CO}_{2}$ 濃度を測定し，図-12に示すようにCO 濃度が定常化 したことを確認し，酸化反応の終息とみなした．以上の 操作を省くと, 圧密過程やせん断過程において供試体が $\mathrm{CO}_{2}$ により不飽和になる. 過酸化水素水を通水した後, 脱気した蒝留水を通水し, 可能な限り過酸化水素水を洗 い出した. B值が 0.95 以上であることを確認し, 飽和と

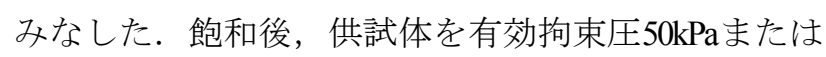
$100 \mathrm{kPa}$ で等方圧密し，ひずみ速度 $0.1 \% / \mathrm{min}$, 排水条件の もと，軸ひずみ $20 \%$ まで軸圧縮した。 なお，最大乾燥密 度に締固めた浄水污泥の透水係数はおよそ $10^{-5} \mathrm{~cm} / \mathrm{s}$ であ ることを文献)で報告しており，上記ひずみ速度であっ ても供試体内に過剩間隙水圧は残留しない.

\section{（2）有機物分解後の浄水污泥のせん断特性}

過酸化水素水および蒸留水を通水したときの陽イオン 溶出濃度の推移を図-13に示す，陽イオンの溶出は，間 隙水の性質を変え，イオン交換などを経て粘土の保水性 やせん断特性は変化することが知られているため ${ }^{20,27)}$, 有機物分解とせん断特性の変化を考察寸る際に, 陽イオ ン溶出特性も併せて把握しておくことは重要である. 過 酸化水素水を通水した場合には, 濃度が切り替わる液固 
比付近において陽イオン溶出濃度は変動したが，溶出濃 度は蒸留水を通水した場合とほとんど同程度であった。 したがって，過酸化水素水通水の有無を比較した場合の 結果の差異は, 有機物分解に起因寸ると限定して考える ことができる.

有機物分解後の浄水污泥の圧密排水三軸圧縮試験にお ける軸差応力および体積ひずみと軸ひずみの関係を図14に示す. CASE1は蒸留水を通水しており, 試験の再現 性を確認した結果，最大軸差応力の差は約7kPaであった。 CASE2 CASE5では過酸化水素水と蒸留水を通水した. 図中に表記した乾燥密度は, 等方圧密後の供試体の乾燥 密度である. 乾燥密度が変動した理由として, 通水と圧 密による体積変化は強熱減量の減少量によらず， 0.53〜 $5.97 \mathrm{~cm}^{3}$ の範囲で体積変化したことが挙げられる. 強熱 減量は, 三軸圧縮試験終了後に測定した供試体上部・中 部・下部の強熱減量の平均值である. 特にCASE4および CASE5のように強熱減量の低下量が大きいほど，軸ひず み約 $5 \%$ 以上の領域において体積ひずみは大きく,すな わち，体積膨張は抑制され，最大軸差応力は減少した.

上記の試験結果を簡略的に検証するため, 過酸化水素 水および水酸化ナトリウム溶液に浸漬することにより事 前に有機物を分解した試料で作製した再構成供試体を用 いて，圧密排水三軸圧縮試験を実施した。試料は，6\% 過酸化水素水または $0.5 \mathrm{~mol} / \mathrm{L}$ 水酸化ナトリウム溶液に 液固比2 L kgで24時間浸漬することを1〜5回繰返し，有 機物の分解を促した．浸漬後の試料を含水比 $44 \sim 50 \%$ ま で室温 $20^{\circ} \mathrm{C}$ で風乾し, 締固めエネルギー約 $102 \mathrm{~kJ} / \mathrm{m}^{3}$ で供 試体を作製した。 B值が 0.95 以上であることを確認し， 有効拘束圧 $50 \mathrm{kPa}$ で等方圧密後, ひずみ速度 $0.1 \% / \mathrm{min}$ で軸 圧縮した．図-15に試験結果を示す．比較のため乾燥密 度0.801 0.804 g/cm³ 範囲に着目すると, 強熱減量が小 さいほど体積膨張は抑制され, 最大軸差応力は減少して おり, 図-14と同様の傾向が確認された.

有機物はセメンテーション効果により土粒子間を結合 することが知られている ${ }^{28)}$. 図-16に示すように, 浄水 污泥は(1)凝集剤による架橋結合と(2)有機物のセメンテ ーションにより団粒構造が形成されていると考えられる. 今回の実験事実に基づけば，有機物が分解されることに より土粒子間の結合力が弱まり，団粒は破砕しや寸くな り，体積膨張は抑制されたと推察される．ただし，浄水 污泥の団粒形成に対寸る有機物のセメンテーション効果 について, 現時点で定量的な情報はないため, 機構解明 にはさらなる調査が要る.

有効拘束圧 $50 \mathrm{kPa}$ よび100kPaにおける圧密排水三軸 圧縮試験における結果より作成したモールの応力円を図 -17に示寸．これより，有機物分解後の浄水污泥の内部 摩擦角 $\phi_{d}$ は $37.9^{\circ}$, 粘着力cは $0 \mathrm{kN} / \mathrm{m}^{2}$ であることが明らかと なった．また，有機物分解が生じない条件においても同

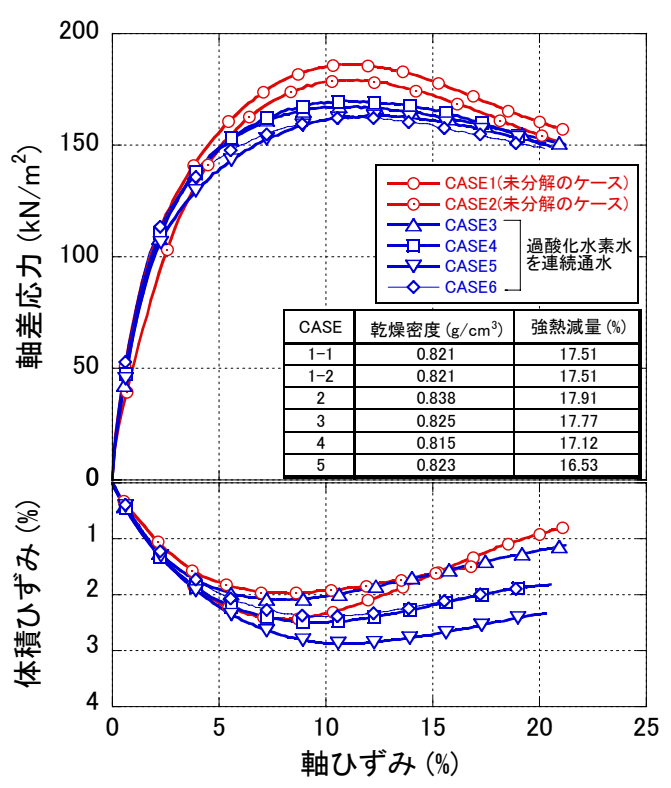

図-14 有機物分解後の浄水污泥の圧密排水三軸圧縮試験 における軸差応力および体積ひずみと軸ひずみの 関係(有効拘束圧 $50 \mathrm{kPa}$ )

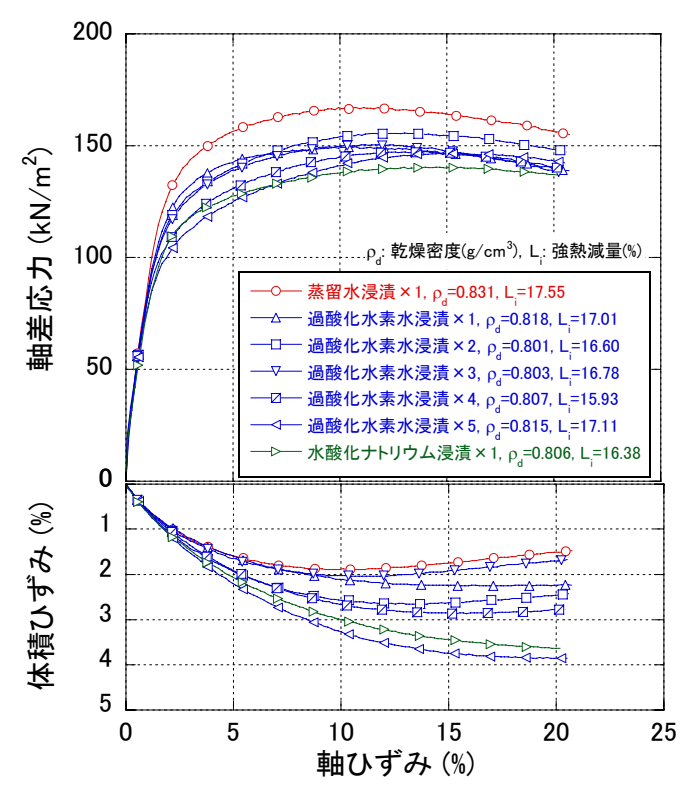

図-15 事前に有機物を分解した浄水污泥の圧密排水三軸 圧縮試験における軸差応力および体積ひずみと軸 ひずみの関係(有効拘束圧 $50 \mathrm{kPa}$ )

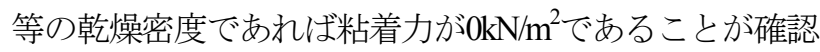
された. 有機物のセメンテーションが減少することによ り浄水污泥は細粒化し, 凝集以前の粘土としての特性が 一部戻ることが予想されたが，本研究で実施した有機物 分解では浄水污泥の団粒は形状を残しており, 砂として の力学特性が顕著であったために粘着力は $0 \mathrm{kN} / \mathrm{m}^{2}$ あ゙あっ たと考えられる. また, 凝集剂としてポリ塩化アルミニ ウムが使用されていたことから，アルミニウム塩の多価 の正電荷により土粒子表面の電荷が中和され ${ }^{13)}$, 電気化 学的な作用が低下したことにより, 粘土としての特性が 
失われていたことも推察される.

粘着力 $0 \mathrm{kN} / \mathrm{m}^{2}$ との実験事実に基づき, 有効拘束圧 $50 \mathrm{kPa}$ よび100kPaの試験結果から内部摩擦角を算出し, 有機物の分解率との関係として図-18に整理した. CASE2およびCASE3については，分解操作後も強熱減量 が高く, CASE1(分解なし)に対する強熱減量の減少割合 を算出できなかったため, 図-18から結果を除外した. 圧密後の供試体の乾燥密度も併記した. CASE1-1および CASE1-2から有機物分解なしの状態における内部摩擦角 は39.7〜 40.4の範囲である. 有機物が約 $1.38 \%$ 減少する ことにより, 浄水污泥の内部摩擦角は $39.7^{\circ} \sim 40.4^{\circ}$ の範囲 から 37.9 付近まで減少することがわかる. 3章の知見よ り，好気環境下において $1.38 \%$ の有機物分解は十分に起 こり得ると言える. 本研究の各実験で使用した試料に関 しては, 有機物分解による内部摩擦角の低下は材料特性 を著しく変えるほどではなかったが, 浄水污泥を地盤材 料として利用寸る上で，表層付近や緩詰めの施工箇所な ぞでは局所的に有機物の分解が進む可能性もあり，その 場合は内部摩擦角が減少することが予想されるため, 有 機物分解による内部摩擦角の低下を考慮して設計定数を 決定するなどの安全上の配慮も有効であると考えられる. なお，本研究では，過酸化水素水を用いて浄水污泥に含 まれる有機物の分解を促進しており, 実際の環境とは分 解プロセスが異なる. 表-5は6\%過酸化水素水に24時間 浸漬した後の有機物等の分解率 $R_{d}$ である. 有機物等の分 解率 $R_{d}$ は式(11)により定義する.

$$
R_{d}=\frac{m_{1}-m_{2}}{m_{1}} \times 100
$$

ここに， $m_{l}$ は含水比を用いて計算した試料の乾燥質量 (g)， $m_{2}$ は $6 \%$ 過酸化水素水に24時間浸漬した後の試料を $110^{\circ} \mathrm{C}$ で24時間炉乾燥した後の乾燥質量 $(\mathrm{g})$ である. フミ ン酸の分解率は $42.5 \sim 46.6 \%$ あった．この值は，図-6に 示した $30 \sim 35^{\circ} \mathrm{C}$ 養生の約 6 力月間で生じるフミン酸の分 解率 $44 \%$ と非常に近い值である. これより, 過酸化水素 水を用いた有機物の分解は自然界における分解とは蕨密 には同意ではないが，浄水污泥の特徴でもあるフミン酸 の分解率に関しては, 好気的な分解と概敉同等の結果が 得られたものと考えられる.

\section{5. 結論}

本研究では, 浄水污泥の有機物組成を明らかにすると 共に，好気環境下における有機物の分解特性を調査した。 その結果, 浄水污泥にはフミン酸が多く含まれており, フミン酸の約44\%は約6力月間で好気分解されることを 明らかにした. また, 有機物分解後の浄水污泥の三軸せ ん断特性を調査することにより，有機物の分解に起因し

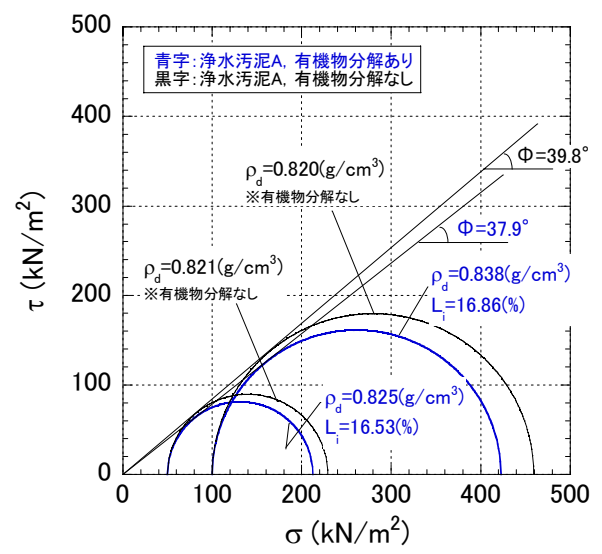

図-17 有機物分解後の浄水污泥の圧密排水三軸圧縮試験 により得られたモールの応力円

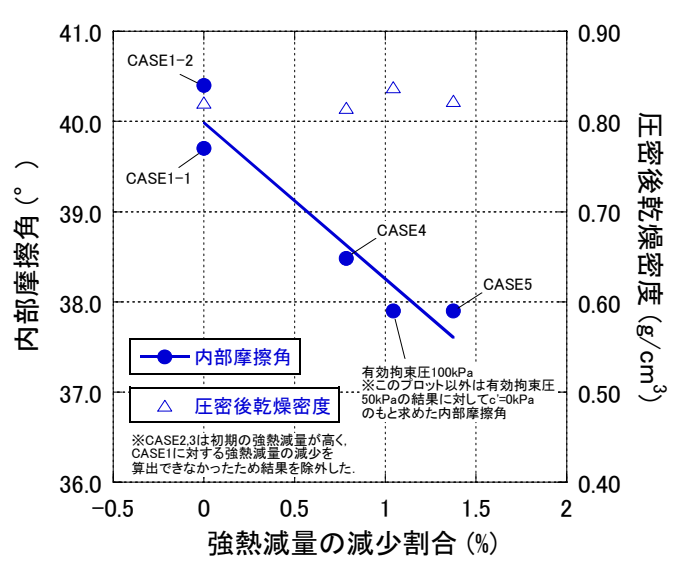

図-18 粘着力 $0 \mathrm{kPa}$ を仮定して求めた内部摩擦角および 圧密後乾燥密度と強熱減量の減少割合の関係

表-5 6\%過酸化水素水に 24 時間浸漬した後の有機物等 の分解率

\begin{tabular}{|c|c|c|c|}
\hline \multirow{2}{*}{ 試料 } & \multicolumn{3}{|c|}{ 有機物等の分解率 $R_{d}(\%)$} \\
\cline { 2 - 4 } & フルボ酸 & フミン酸 & $\begin{array}{c}\text { ヒューミンを含 } \\
\text { む土粒子 }\end{array}$ \\
\hline $\mathrm{B}$ & 77.1 & 44.9 & 3.1 \\
\hline $\mathrm{C}$ & 86.5 & 43.2 & 8.1 \\
\hline $\mathrm{D}$ & 88.0 & 46.6 & 10.3 \\
\hline $\mathrm{E}$ & 73.4 & 42.5 & 6.6 \\
\hline
\end{tabular}

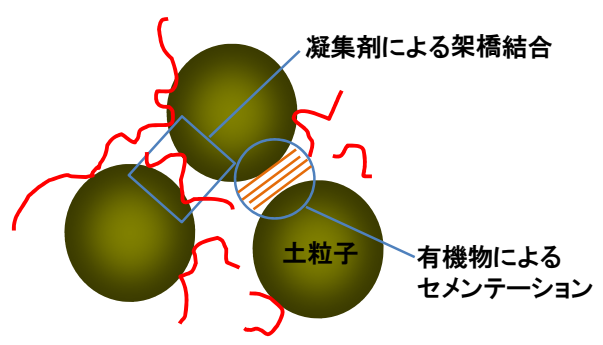

図-16 浄水污泥の団粒構造における凝集剤および有機物 の結合形態の概念 
て浄水污泥のせん断強度は低下寸ることを明らかにした。 本研究で実施した実験では, 約1.38\%の有機物が分解さ れることにより, 内部摩擦角は39.7〜 40.4の範囲から 37.9 付近まで減少し, また, 粘着力は有機物の分解によ らず $0 \mathrm{kN} / \mathrm{m}^{2}$ であった．本研究では，過酸化水素水を用い て有機物の分解を促進したが，フミン酸の分解に限定す れば，好気分解の場合と概初同等の分解率であった。し たがって, 浄水污泥の利用条件次第では有機物の分解は 十分に起こり得ることであり，また，有機物の分解はせ ん断特性に影響を及ぼすことから，有機物の分解に関す る検討を進めることが浄水污泥の安全かつ適正な利用に 結びつくと考えられる.

謝辞 : 本論文で報告した実験データは，第一著者が茨城 大学在学中に取得したものである.ここに感謝の意を表 します.

\section{参考文献}

1) 厚生労働省健康局水道課 : 浄水污泥(浄水発生土)の循 環利用について, 第58回中央環境審議会循環型社会 計画部会，資料 $4 ， 2010$.

2) 厚生労働省健康局水道課：水道事業における環境対 策の手引書(改訂版), 第III編水道事業における環境対 策の具体例，pp. 68-95， 2009.

3) 古河幸雄, 曾津大三, 藤田龍之: 浄水污泥の地盤材 料一の利用に関する研究，土木学会論文集C，Vol.62， No.1, pp.67-78, 2006.

4) Roque, A. J. and Carvalho, M.: Possibility of Using the drinking water sludge as geotechnical material, Proc. of $5^{\text {th }}$ International Congress of Environmental Geotechnics, pp.1535-1542, 2006.

5) 渡邊保貴, 小峯秀雄, 安原一哉, 村上哲, 豊田和 弘 : 浄水污泥のアルミニウム溶出に関寸る環境影響 評価手法の提案, 土木学会論文集G, Vol.65, No.3, pp.188-201, 2009.

6) 渡邊保貴, 小峯秀雄, 安原一哉, 村上哲, 豊田和 弘：凝集剂成分の溶出を伴う乾湿繰返しを受けた浄 水污泥の圧縮性および透水性の評価, 土木学会論文 集C, Vol. 66, No. 3, pp. 550-563, 2010.

7) 渡邊保貴, 小峯秀雄, 安原一哉, 村上哲, 豊田和 弘：環境経済効果に着目した浄水污泥と砂質土の混 合利用，土木学会論文集C，Vol. 66，No. 4, pp. 788799, 2010.

8) 中村公亮, 佐藤研一, 山田正太郎, 藤川拓朗, 長浜 武知, 木之下盛博: 浄水污泥を用いた粒状改良土の 材料特性, 第 40 回地盤工学研究発表会講演集(CDROM), 2005.

9) 嘉門雅史, 浅川美利: 新体系土木工学16土の力学(I), 技報堂出版, 1988 .

10) M. M. コノノワ[著], 菅野一郎ら[訳] : 土壌有機物一
その本質・性質および研究法, 農山漁村文化協会, pp. 50-61, 1976.

11) Sparks, D. L.: Environmental Soil Chemistry, second edition, Academic Press, 2003.

12) Ohkubo, N., Yagi, O. and Okada, M.: Effects of humic and fulvic acids on the growth of microcystis aeruginosa, Environmental Technology, Vol. 19, pp. 611-617, 1998.

13）丹保憲仁，小笠原紘一：浄水の技術, pp.37-59, 技報 堂出版, 2002.

14) ウィリアム・ジュリー, ロバート・ホートン[著], 井 上光弘, 長裕幸, 西村拓, 諸泉利嗣, 渡辺晋生[訳] : 土壤物理学 土中の水・熱・ガス・化学物質移動の基 礎と応用, 三美印刷, 2006.

15) 土壌微生物研究会：土と微生物, 岩波書店, 1966.

16) Plante, A. F., Conant, R. F., Carlson, J., Greenwood, R., Shulman, J. M., Haddix, M. L. and Paul E. A.: Decomposition temperature sensitivity of isolated soil organic matter fractions, Soil Biology and Biochemistry, Vol. 42, pp. 1991-1996, 2010.

17) 坂本一憲, 吉田富男: 土畩呼吸速度による土䁃バイ オマスの測定, 日本土壤肥料学雑誌, 第59巻, 第4号, pp.403-409, 1988.

18) 野口航 : 個葉から葉緑体スケールのガス交換 c. 呼吸 速度 $\left(\mathrm{CO}_{2}\right.$ 発生速度)測定, 低温科学, Vol.67, pp.83-87, 2009.

19) 別宮有紀子, 坂田剛：根の呼吸の日中変動とその要 因 : 根と葉の結びつきを考慮した生態学研究の新た な可能性, 日本生態学会誌, No.59, pp.55-63, 2009.

20) 田中信壽：環境安全な廃棄物埋立処分場の建設と管 理，技報堂出版， 2004 .

21) Jenny, H.: Factors of Soil Formation, McGraw-Hill, New York, 1941.

22）井ノ子昭夫：土壤中における有機物の分解と集積一 その数式化へのアプローチ一，日本土㙴肥料学雑誌， 第52巻, 第6号, pp. 548-558, 1981.

23) Pietruszka, M.: General proof of the validity of a new tensor equation of plant growth, Journal of Theoretical Biology, Vol. 256, pp. 584-585, 2009.

24) 地盤工学会 : 地盤調査の方法と解説(第1刷), p. 561, 丸善, 2004.

25）磯秀幸, 渡邊保貴, 小峯秀雄, 村上哲, 豊田和弘： 室内CBRに基づく浄水污泥の路床材としての品質管 理方法の提案, 第46回地盤工学研究発表会講演集 (CD-ROM), 2011.

26）日本粘土学会 : 粘土ハンドブック，第二版，技報堂 出版, 1994.

27) Warkentin, B. P. and Yong, R. N.: Shear strength of montmorillonite and kaolinite related to interparticle forces, Clays and Clay Minerals, Vol. 9, pp. 210-218, 1962.

28) Mitchell, J. K. and Soga, K.: Fundamentals of Soil Behavior, third edition, John Wiley \& Sons, 2005.

(2011. 7.21 受付) 


\section{FUNDAMENTAL STUDY ON RELATION BETWEEN ORGANIC MATTER DECOMPOSITION AND SHEAR STRENGTH OF DRINKING WATER SLUDGE}

\section{Yasutaka WATANABE, Hideo KOMINE, Satoshi MURAKAMI, Kazuya YASUHARA and Kazuhiro TOYODA}

Drinking water sludge discharged during water purification contains a lot of organic matter. The generation process of drinking water sludge is quite different from that of general soils, so the influence of organic matter decomposition on the engineering properties is not interpreted enough. Therefore, it is important to investigate the decomposition characteristics of organic matter of drinking water sludge, and to discuss the relation between the organic matter decomposition and shear strength. First, this study isolated fulvic acid and humic acid, and observed the organic matter decomposition and soil respirations. The humic acid content of drinking water sludge was relatively high, and $44 \%$ of humic acid was decomposed during 6 month in aerobic condition. Second, triaxial compression tests were executed using the sludge that organic matter has been decomposed by hydroperoxide solutions. Approximately $1.38 \%$ of organic matter decomposition showed decrease in the internal friction angle from $39.7^{\circ}-40.4^{\circ}$ to around $37.9^{\circ}$. 